\title{
The Statement of Principles of Christian Law: A Quaker Perspective
}

\author{
FRANK CRANMER ${ }^{1}$ \\ Fellow, St Chad's College, Durham \\ Honorary Research Fellow, Centre for Law and Religion, Cardiff University
}

\begin{abstract}
An ecumenical group of experts in church law produced a Statement of Principles of Christian Law based on a comparative examination of the internal regulations of their respective churches. This article examines the detail of the Statement from the point of view of the regulations and practice of Quakers in Britain and concludes that, based as it is on a Trinitarian, sacramental view of 'the Church', while there is much in it with which Friends and members of other non-sacramental, non-hierarchical denominations - would agree, there is also much which has little resonance for them.
\end{abstract}

Keywords: church law, government, doctrine, sacraments, ministry, ecumenism, Quakers

\section{INTRODUCTION}

In 2017, the Journal published the Statement of Principles of Christian Law formulated as a result of an examination by a panel of experts of their internal regulatory instruments and 'offered for further examination by comparative scholars of church law, as an expression of shared ecclesiology, and in furtherance of the ecumenical endeavour'. What follows is the personal perspective of a Quaker with an academic interest in ecclesiastical law and ecclesiology. It should be emphasised that it does not purport to represent the corporate views of the Religious Society of Friends in Britain: no individual Friend may do so without the express authority of Britain Yearly Meeting ('BYM'). ${ }^{3}$ It should also be noted that it is written from within the context of the liberal Quaker tradition in Great Britain: Friends in other parts of the world would not necessarily share the views expressed.

1 Thanks are due to Michael Booth, Church Government Advisor at Friends House, for his helpful comments on a draft - but that in no way represents any kind of nihil obstat, still less an imprimatur.

2 M Hill and N Doe, 'Principles of Christian law', (2017) 19 Ecc LJ 138-155.

3 Which until 1995 was known as London Yearly Meeting. 


\section{THE BASICS}

For readers who are unfamiliar with Quakers, it may be helpful to outline briefly some of the basics of British Quaker belief and practice. ${ }^{4}$ The core activity of Friends who stand in the 'unprogrammed' tradition - the classic Quaker style of worship dating back to the movement's founder, George Fox - is Meeting for Worship: the Quaker equivalent to what other denominations do on a Sunday morning. There is no liturgy or music of any kind; instead, Friends sit in silence until someone is moved to say something - or, in Quaker-speak, 'to minister'. If no-one is moved to minister, the meeting passes in total silence. That happens not infrequently; and even in a 'busy' meeting there is likely to be much more silence than speech: 'The silence of Meeting is not a gap; it is, rather, the essence of Meeting. ${ }^{5}$ As to theology, Friends do not subscribe corporately to the traditional Christian creeds; indeed, there is a perennial, low-level debate within the movement on the question 'But are Quakers Christian?' that can probably never be resolved. Local Meetings are grouped into Area Meetings, which meet roughly once a month ${ }^{6}$ to consider areas of common interest and concern and to exercise oversight of the Local Meetings in their areas.

Quakers in Britain and Quakers in the unprogrammed tradition internationally do not have any separate class of ordained clergy, nor, given that Friends are strictly non-sacramental, are there many traditional 'clerical' functions to perform. ${ }^{7}$ The Society employs a small full-time administrative staff to administer its day-to-day affairs in matters such as property, trusts and publications, but the basic principle of governance within the Society is that all members are of equal standing and there is nothing that corresponds to the hierarchies of the more traditionally grounded denominations. Nor do Friends regard the administration of the secular affairs of the Society as being qualitatively different from worship. A local business meeting at which the affairs of the Society are considered is more formally described as 'Meeting for Worship for Business' ${ }^{8}$ and, for

In the United States, for example, there is a division between those whose practice resembles that of British Quakers and more Bible-based groups. In 1828-1829 American evangelicals who wanted to adopt a statement of faith split from liberals who did not: E Livingstone (ed), Oxford Dictionary of the Christian Church (third edition, Oxford, 1997), p 766. American 'Orthodox', 'Conservative' or 'Evangelical' Friends hold to the priesthood of all believers but take a high view of Scripture, employ stipendiary pastors and hold liturgical services with readings, hymns and sermons known as 'programmed worship'. Some of the most conservative even persist in using 'thee' as a nominative. In the US, liberal Friends are in the minority.

5 A Bradney and F Cownie (2000), Living Without Law: an ethnography of Quaker decision-making, dispute avoidance and dispute resolution (Aldershot, 2000), p 137.

6 They used to be called 'Monthly Meetings'.

7 In which context, it should be noted that activities such as prison ministry, hospital chaplaincy, the arrangement of funerals, and chaplaincy in institutions of further and higher education are often undertaken by laypeople even in churches with a separate class of clergy. 
Friends, a Meeting is a Meeting is a Meeting - so a meeting to discuss property or finance is just as much 'worship' as Meeting for Worship on a Sunday morning.

\section{QUAKERS AND 'RIGHT ORDERING'}

However fluid their theology, Friends regard the 'right ordering' of worship and the conduct of business as essential to the Society's life; and that principle manifests itself in various ways. The document that is generally regarded as the first attempt to create an ordered Society is The Epistle from the Elders at Balby, $16{ }_{5} 6$, 'unto the brethren in the north'. 'The first embryonic rules were published very early in the life of the Society as Friends Fellowship (1668), reprinted in the following year under the rather surprising title Canons and Institutions. ${ }^{10}$ The Canons propose, for example, that 'Friends do buy convenient burying-places, as Abraham did, who bought a place to bury his dead ... and let them be decently and well fenced' and that 'Friends buy convenient books for registering the Births, Marriages, and Burials'. The embryonic Canons gradually evolved into more formal, detailed texts on the regulation of the Society, and in 1783 London Yearly Meeting published its first book of discipline, entitled Extracts from the Minutes and Advices of the Yearly Meeting of Friends Held in London. ${ }^{11}$

From time to time, BYM publishes a manual on questions of faith, conduct and discipline. The first edition of the current book of discipline, Quaker Faith \& Practice ('QFP'), was circulated in draft to every Preparative Meeting in Britain for comment, and the published version was significantly revised as a result. It includes Advices and Queries, ${ }^{12}$ more general theological issues such as approaches to God, discipleship, the Peace Testimony and social responsibility - and the Society's rules. ${ }^{13}$ The current, fifth, edition was published in 2013 but the online version has been updated subsequently: most notably, Chapter 16 , on Quaker marriage procedure, was revised to reflect changes approved by BYM in 2015 following legislation permitting same-sex marriage in England and Wales from March 2014 and in Scotland from December 2014. ${ }^{14}$ At the time of writing, preparations were beginning for an entirely new book of discipline, rather than a updated sixth edition of QFP, as agreed

9 Available at <http://www.qhpress.org/texts/balby.html>, accessed 2 June 2018.

10 Canons and Institutions drawn up and agreed upon by the General Assembly or Meeting of the heads of the Quakers from all parts of the kingdom at their New-Theatre in Grace-church-street in or about January 1668/9; George Fox being their president (London, 1669).

11 T Hamm, 'The best written code: a brief history of Quaker books of faith and practice', (2013) 59 Friends Journal $10-13$ at 11.

12 Largely a series of questions commended as an aid to self-examination 'for the comfort and discomfort of Friends' (QFP, 1.01).

13 Other Yearly Meetings have similar handbooks: see, for example, Philadelphia YM's Faith and Practice (revised 1997) and New York YM's Faith and Practice (revised 1998).

14 The updated text is available online at $<\mathrm{http} / /$ qfp.quaker.org.uk $>$, accessed 2 June 2018. 
at Yearly Meeting 2018. The process will look at the content of the book as a whole, including the historical and 'theological anthology' sections.

Friends set great store by 'right ordering': that everything should be done in accordance with Quaker tradition and practice. Right ordering, however, goes far beyond rigid adherence to QFP; in any business meeting, if there is any doubt whatsoever about the propriety of a proposed course of action, someone will almost inevitably ask the crunch question: 'But is it in right ordering?' It is as much an attitude of mind as respect for the rulebook.

\section{THE STATEMENT: THE PROBLEMATIC, THE UNPROBLEMATIC AND THE IRRELEVANT}

To turn to the detail of the Statement, many of its basic propositions can be applied to almost any religious organisation, Christian or not; equally, some are very far removed from the experience and profession of Friends.

\section{Churches and their systems of law, order and polity}

Many of the statements in sections I.4 and I.5 on the structure, effect and relaxation of norms and the interpretation of law are unexceptionable, though the reference in I.5.3 to 'the mind of the legislator' implies a fairly rigid and hierarchical system of rule-making. Equally, many of the statements in section I.1 ('The institutional church') - that a church as an institution may define itself by its autonomy, polity and objects; may be international, national, regional or local; and has a distinct membership, or other body of persons associated with it, which may be organised in territorially or non-territorially - apply equally to Friends as to other denominations.

Where difficulties arise, it is with such statements as 'A church has amongst its objects the advancement of the mission of Christ which includes proclaiming the Gospel, administering the sacraments, and serving the wider community' and 'Communion amongst the faithful is an essential quality of ecclesial life'. As to the first, Friends are non-sacramental and very few would feel comfortable with the expression 'proclaiming the Gospel', partly because it is virtually meaningless in a modern Quaker context and partly because, although the Society is very much concerned with social action and the wider community, Friends are very reluctant to do anything that might look like proselytising. As to the second, 'communion' has obvious eucharistic overtones: 'community' or 'common life' would be more acceptable terms for Quakers.

Section I.2 merely describes the common basis for any kind of regulation whatsoever, from the Codex Iuris Canonici 1983 to the rules of a golf club. Section I.3 ('The servant law') is less obviously applicable to Friends, however - principally because the purpose of Quaker regulation is much more limited than this section suggests. I would suggest that its purpose is not 'to serve a church in its mission and in its witness to the salvific work of Christ' but, 
rather, to help us explore what it means to be a Friend in the early twenty-first century and to make sure that the Society conducts itself in right ordering. Similarly, the proposition in section 4 that 'Church laws should conform to the law of God, as revealed in Holy Scripture and by the Holy Spirit' is based on an a priori - but unsubstantiated - assumption that 'the law of God' can be readily deduced from the Bible, and appears to accept, at least implicitly, the concept of 'natural law'.

\section{The faithful}

Where, I suspect, Friends would begin to part company from the 'Universal Church' - however defined - is on issues such as some aspects of section II. As to II.1 ('The People of God'), in the absence of any concept of baptism or ordination, statements about them are irrelevant. Friends would certainly agree, however, that 'All the faithful should be equal in dignity'. Not only is the Testimony to Equality a core tenet of the Society but Friends would assert that, in not having any kind of hierarchy of persons 'set apart' from the membership as a whole, they walk the talk in a way that hierarchical churches do not:

When early Friends affirmed the priesthood of all believers it was seen as an abolition of the clergy; in fact it is an abolition of the laity. All members are part of the clergy and have the clergy's responsibilities for the maintenance of the meeting as a community. ${ }^{15}$

That, inevitably, carries over into any consideration of II.3 ('The functions of the laity'). For Friends, talk of 'the laity' is just as meaningless as talk of 'the clergy'. In its response to the ARCIC statement The Gift of Authority, the BYM Committee for Christian and Interfaith Relations noted that

In our understanding 'the Church' is precisely what the document calls 'the laity' - laos, the whole people of God - i.e. an undivided body of men and women who minister to one another in a mutual priesthood modelled on the servant priesthood of Jesus. ${ }^{16}$

One item that does resonate, however, is II.3.4: 'Lay persons should maintain such Christian standards in their private lives as are prescribed by law'. No-one becomes a member of Quakers in Britain by accident - not even by accident of birth $;{ }^{17}$ all adult members are Quakers 'by convincement' and there is very little point in becoming a Friend unless one tries to observe Quaker 
standards at all times. That is not to suggest that every Friend always gets it right - almost certainly the most famous (or notorious) Quaker of the last century was one Richard Milhous Nixon - but it does mean that no Friend who took his or her Quakerism at all seriously would intentionally apply different standards of personal behaviour to public and to private activities.

\section{Ordained ministry}

Almost inevitably, section III is largely irrelevant to Friends, given that they have neither clergy nor hierarchy. Each Meeting appoints a number of elders and overseers:

Traditionally the first concern of elders is for the nurture of the spiritual life of the group as a whole and of its individual members so that all may be brought closer to God and therefore to one another, thus enabling them to be more sensitive and obedient to the will of God. So the right holding of our meetings for worship will be their particular care. The chief concern of overseers is with the more outward aspects of pastoral care, with building a community in which all members find acceptance, loving care and opportunities for service. ${ }^{18}$

Elders and overseers, however, are not qualitatively different from their fellow Quakers. Current practice within BYM is that both elders and overseers hold office for three years, renewable for a further three but not normally thereafter. Moreover, 'Appointment as elder or overseer does not imply that the Friends concerned are elevated to a higher position but that the meeting recognises that they may have the capacity to serve it in a particular way. ${ }^{19}$

Friends would agree, however, with sections III.4.1 and 2 that oversight is 'an essential of ecclesial order' and is 'exercised by such authority as is designated by law'. Oversight exists, but it is corporate rather than personal: perhaps the oversight that Area Meetings exercise over their Local Meetings can best be compared with the oversight in the Church of Scotland exercised by the presbytery of the bounds over its constituent kirk sessions.

\section{Church governance}

From a Quaker perspective, section IV begins with two statements that, I suspect, have no great resonance for at least a significant number of British Friends: IV.1.1, 'Christ is the ultimate head of the Church universal in all its manifestations', and IV.1.2, 'A system of government used by a church reflects its conception of divine law'. Otherwise, there is nothing in the section on 
governance to which Friends could take exception, though it should be noted that, with the exception of Meeting for Sufferings, ${ }^{20}$ to which delegates are sent by Area Meetings, any member may attend Yearly, Area and Local Meetings. So the statement at IV.5.4 that 'The assembly of a local church is composed of those members of the faithful who are lawfully elected or otherwise appointed to it' has no obvious relevance to Quaker practice: a Local Meeting for Business is composed of all those who attend Meeting for Worship.

As to Quakers worldwide, Yearly Meetings are regarded as autocephalous, though some have joined in co-ordinating bodies such as Friends United Meeting, an association of 26 Yearly Meetings in North America, Africa and the Caribbean to which they have ceded a certain degree of authority. Friends World Committee for Consultation, which since 1948 has had consultative status with the United Nations and is responsible for the two Quaker UN Offices in Geneva and New York, is, as the name suggests, a worldwide body, but it does not claim any theological authority over its constituent Yearly Meetings.

\section{Church discipline}

The opening proposition in section V, that 'All the churches have a system of discipline, the administration of which is regulated by norms which deal with the purpose and scope of discipline and processes to enforce it', is unexceptionable, if by that it is meant that every denomination must have at least some boundaries that cannot be transgressed without sanction, the most obvious of which would be breaches of the criminal law or of the fiduciary duties of trustees.

Much of what follows, however, appears to relate more appropriately to denominations that operate through a hierarchical system of councils or courts than to a much more loosely structured organisation like the Society of Friends. As to V.1.1, the Society as an institution certainly 'has the right to enforce discipline', in the sense that a golf club has the right to enforce discipline among its members; and a Friend who advocated the use of nuclear weapons would, at the very least, be asked politely to reflect on whether or not that position was consonant with Quaker practice. Similarly, if Friends disagree about how to address a particular issue, they might try to talk through the problem to see if they can discern a way forward, or they might invite other Friends not directly involved in the matter to a Meeting for Clearness to see if further worshipful discussion might lead to a resolution ${ }^{21}$ or to a Threshing Meeting, 'at which a variety of different, and sometimes controversial, opinions can be openly, and sometimes forcefully, expressed, often in order to defuse a situation

The de facto executive of BYM which acts on its behalf when BYM is not in session: it has about 200 members who meet five times a year. It began in 1675, at a time when Quakers were frequently imprisoned for their faith: initially to obtain redress in particular 'Cases of Suffering': see QFP, ch 7 . 
before a later meeting for worship for business'. ${ }^{22}$ Or they might simply depart from the issue, on the basis that not every problem has a solution.

As to V.1.4, few Friends would recognise the purpose of discipline as 'to glorify God'; however, all Friends are concerned to protect the integrity and mission of the Society, and especially to safeguard the vulnerable from harm and to promote the spiritual benefit of those who come to Meeting. As to V.1.5, such discipline as there is, is exercised in accordance with QFP.

The absence of a separate class of clergy apart, it is perhaps in the areas of dispute resolution (whether formal or informal), church courts and tribunals, due process, and ecclesiastical offences and sanctions where the practice of Friends departs most radically from, for example, the Roman Catholic, Anglican or Presbyterian model of a structure of courts or councils. A brief description of the Quaker business method will explain why it should be so.

The primary objective of the Quaker method of conducting Meetings for Business is to seek unity in decisions: to find a way forward that all present can accept. Not everyone will necessarily agree with the outcome wholeheartedly; the aim is to come to a decision that reflects the sense of the meeting after all views have been heard and considered. As noted earlier, Friends make no distinction between different kinds of meeting: a Meeting for Business is equally a Meeting for Worship, and will always begin with a period of silence.

Every meeting for business is facilitated by a Friend who is appointed as clerk. The clerk prepares the agenda, is responsible for administration and presides at the meeting and ensures its smooth running. The usual procedure is that the clerk announces the agenda item, possibly gives some brief explanation of its context, invites discussion and listens as it unfolds. The convention is that, if possible, no Friend speaks more than once to an item and the Friends do not repeat unnecessarily what has already been said. When the clerk feels that the meeting may be coming to some kind of consensus, he or she will draft a minute recording the decision and offer it to those present. If Friends accept the draft minute, that will bring discussion on that item to a close; if not, discussion will continue and, at some point, the clerk will offer the meeting a revised minute. The process continues until either a consensus is reached or, occasionally, it is clear that there can be no meeting of minds and the matter is departed from. It is not uncommon, however, for a Friend who has a lingering doubt to state that, in the interests of reaching a decision, he or she will not impede the draft minute presented by the clerk. ${ }^{23}$ Crucially, there are no votes: the meeting proceeds by discussion and the discernment of consensus, not by counting heads. The Quaker business method may seem strange to those who have not experienced it and possibly rather cumbersome; but it has the great merit of

23 For the duties and role of clerks, see QFP, 3.13-3.20. 
ensuring that all opinions are heard and taken into account and, crucially, that the whole Meeting has ownership of what is finally agreed.

As to appeals against decisions, the current procedure is set out in QFP as follows. A member dissatisfied with a final decision of an Area Meeting affecting her or him (for example, termination of membership), who feels that the decision was unjust, unreasonable, taken with insufficient knowledge or not in right ordering, may appeal in writing to the Area Meeting clerk. The nature of the appeal and the appellant's name should be kept confidential so far as is possible or is desired by the appellant. The Area Meeting then appoints a small group of disinterested Friends to try to settle the matter. If that fails, it should then ask a neighbouring Area Meeting to appoint a small group of disinterested elders to act as an appeal group. The appeal group should meet with the appellant and representatives of the respondent Area Meeting and give a judgment to that Area Meeting - so far as possible without breaking confidentiality. The respondent Area Meeting should accept that judgment, at which stage the decision should become as public as is needed for the matter to be acted upon.

An appellant who is still dissatisfied may then appeal further to Meeting for Sufferings, which will appoint an appeal group of five Friends, who should be independent of the Area Meeting concerned, to inquire into the matter and determine whether or not the appeal should be allowed and whether any further recommendations should be made. The decision of the Meeting for Sufferings appeal group is final and Meeting for Sufferings minutes the decision without breaking the confidentiality of the parties concerned. Guidelines for the conduct of an appeal group are obtainable from the Recording Clerk. ${ }^{24}$

Finally, an Area Meeting that is dissatisfied with a final decision of another Area Meeting that affects it may appeal that decision to Meeting for Sufferings. The procedure on such an appeal is similar to that on an individual appeal, but the dissatisfied Area Meeting must give prior notice to the other Area Meeting concerned before invoking the procedure. ${ }^{25}$

Such appeals are fairly rare. That an appeal group will consider the matter before it objectively and without prejudice is simply assumed - not least because its proceedings, like those of all Quaker committees, will be conducted in the context of worship. However, the system of appeals is currently under consideration, Meeting for Sufferings having concluded in April 2018 that appeals should be restricted solely to the termination of membership where mediation has already failed and that the grounds of appeal should be only that the decision was not made in right ordering, was not made with knowledge of the relevant facts or was unreasonable. ${ }^{26}$

26 For the detail, see the Meeting for Sufferings Calling Letter and Agenda, 23 March 2018, MfS 201804 o6, available at <https://quaker-prod.s3.eu-west-1.amazonaws.com/store/ 86eed2780of23b822af5151201f859617da531916f4dafc2oae3baf4625d >, accessed 3 June 2018. 


\section{Doctrine, worship, proclamation and discipline}

As may be evident from the foregoing, Friends - at least in the unprogrammed, British tradition - are very concerned about the right conduct of worship but have relatively little interest in doctrine. The statement which begins Section VI, that the doctrine of a church 'is rooted in the revelation of God as recorded in Holy Scripture, summed up in the historical Creeds, conveyed in tradition, and expounded in instruments, texts and pronouncements issued by persons and institutions with lawful authority to teach', probably has little resonance for the majority of them.

It is true that, as VI.1.1 observes, 'The doctrinal instruments of churches may have elements which themselves may generate norms of conduct' - at least insofar as Friends can be said to have such a thing as 'doctrine' at all. But most Quakers are not interested in orthodoxy - what concerns them is orthopraxy. It is probably true to say that, ultimately, what Friends believe is what the consensus is among Friends generally at that particular point in time - the ultimate manifestation of the consensus fidelium.

However, as to the statement in VI.1.2 that doctrines 'may be interpreted and developed afresh to the extent and in the manner prescribed by law', it is essential that they be so. Some of the issues that concerned Friends in the seventeenth and eighteenth centuries were very different from those that concern Friends in the twenty-first. That is why the book of discipline - currently QFP - has undergone fairly regular revisions: what it meant to be a Friend even 50 years ago is not necessarily what it means to be a Friend now.

Little of Section VI.2 is relevant to Quaker experience. Friends do not 'preach'; and if 'vocal ministry' is in some sense the Quaker equivalent of 'preaching', then it is the shared responsibility of the Meeting. Moreover, in a Quaker Meeting for Worship, anyone present who feels moved to minister may do so. ${ }^{27}$ Nor is the statement in VI.2.5 about the authority of the Bible broad enough: biblical texts must certainly 'be treated respectfully and coherently, building on tradition and scholarship', but Friends would seek to treat all texts - from the Bible to the Bhagavad Gita to the European Convention on Human Rights - 'respectfully and coherently'.

Likewise with much of Section VI.3: Friends certainly recognise 'a right to enforce [our] own doctrinal standards and discipline' and would hope that members and attenders would 'believe church doctrine' insofar as it exists or why would they be attending Meeting for Worship at all? - but 'enforcing' doctrine is not something that looms large in Quaker practice. As to VI.3.6,

27 Though if someone ministers at excessive length or makes statements that appear unQuakerly, that person might be reproved - quietly and very gently - by one of the elders after the meeting has ended. That said, I have never known it happen, nor, when I was an elder, did I ever do such a thing myself. 
on determining 'the limits of permissible theological opinion and ... doctrine and doctrinal standards', those limits are extremely wide - though if a group of Friends started agitating for increased military spending, contrary to the Peace Testimony, they might reasonably be asked in what sense they could still regard themselves as Quakers.

As to worship, in a Quaker context it should be remembered that not all Friends would describe themselves as Christians. Some are atheists or agnostics, ${ }^{28}$ many others see strong parallels between Quakerism and the Buddhist tradition, ${ }^{29}$ while yet others are also members of other denominations. ${ }^{30}$ So for some Friends, Meeting for Worship is certainly about 'worship' but not necessarily about 'God' - so much so that one of the issues that will be addressed in the forthcoming revision of the book of discipline will be the extent to which references to 'God' continue to be relevant to Quaker experience in the early twenty-first century. Similarly, though it is undoubtedly the case that, as VI.4.3 observes, churches 'may develop liturgical texts or other forms of service for the public worship of God provided these are consistent with the Word of God and church doctrine', Friends do not have 'forms of service' except, perhaps, for the exchange of wedding vows - which must be in conformity with the provisions of the Marriage Act 1949 or the Marriage (Scotland) Act 1977 , as appropriate, and subsequent legislation.

As to the statement in VI.5.1 that a church 'must provide for public worship', that must be the case for England and Wales because if a church of chapel does not do so it will be unable to register under the Places of Worship Registration Act $1855 .{ }^{31}$ The test for registration is that what goes on inside the building must be both 'public' and 'worship', so, for example, a request to register religious buildings to which the public were not admitted has been refused,,$^{32}$ while there has been a protracted controversy over whether or not the services of the Church of Scientology constitute 'worship'. ${ }^{33}$ Moreover, a church that does not 'provide for public worship' may well lose its charitable status under secular law because it will not be providing 'public benefit' within the meaning of the secular legislation. ${ }^{34}$

See, eg, D Boulton (ed), Godless for God's Sake: nontheism in contemporary Quakerism (Dent, Cumbria, 2006).

29 See, eg, J Pym, Listening to the Light: how to bring Quaker simplicity and integrity into our lives (London, 1999).

30 Perhaps the best known is the Revd Canon Paul Oestreicher, an Anglican priest who from 2004 to 2009 was also honorary Quaker chaplain to the University of Sussex.

31 But not in Scotland, where there is no system of registration.

32 Church of Jesus Christ of Latter-Day Saints v United Kingdom App no 7552/09 (ECtHR 4 March 2014).

$33 R v$ Registrar General ex $p$ Segerdal \& Anor [1970] 3 All ER; $R$ (Hodkin \& Anor) v Registrar-General of Births, Deaths and Marriages [2013] UKSC 77.

34 See, eg, Cocks v Manners (1871) LR 12 Eq 574 and Gilmour v Coats [1949] AC 426, both of which held that a bequest to an enclosed religious order was not for the public benefit and therefore not charitable. 
As noted above, the conduct of public worship is the shared responsibility of all those present, with minimal supervision by the Meeting's duty elders. Regular attendance is an expectation on Friends but no distinction is made between one day and another, on the principle that all time is sacred. Early Friends referred to the days of the week and the months of the year as 'first day, second day ...' and 'first month, second month ...'.

\section{The rites of the Church}

Section VII begins with the statement that 'All the churches have rites of passage which mark the stages in the spiritual life of the Christian.' Apart - obviously from marriage and burial, the only 'rite of passage' of relevance to Friends is reception into membership. An applicant is visited by two Friends to discuss his or her application and those Friends report back to Area Meeting - which decides whether or not the applicant is to be received as a member. ${ }^{35}$

As to marriage, for Friends in Britain its foundations are the Marriage Act 1949, as amended, the Marriage (Scotland) Act 1977, as amended, the Marriage (Same Sex Couples) Act 2013 and the Marriage and Civil Partnership (Scotland) Act 2014. Friends are one of the few denominations in the UK that perform same-sex marriages and would heartily agree with the statement in VII.4.3 that marriage 'is for the well-being of the spouses' - whatever their sexual orientation. As to the legal formalities, Quaker marriage procedure in England and Wales is prescribed by section 47 of the Marriage Act 1949 (Marriages according to usages of Society of Friends) and is 'celebrated in the presence of an authorised person': the Area Meeting's registering officer, who makes the return to the General Register Office. Quaker marriages are registered and are 'ended by the death of one of the spouses and may be dissolved when so determined by competent authority' - the 'competent authority' being, for Friends, the secular courts.

As to funerals, it is the custom for Friends who die to be given a Quaker funeral or cremation service - which is a Meeting for Worship like any other. Unlike many other denominations in the United Kingdom which are experiencing severe shortage of burial plots, however, Friends still have open burial grounds.

\section{Ecumenism}

Possibly the most difficult part of the Statement from a Quaker point of view is Section VIII, on ecumenism. There may well be, as VIII.1.1 asserts, 'one, holy, catholic, and apostolic Church': if so, Friends are only a tiny part of it and possibly its most eccentric outlier. Friends would no doubt agree with the statement 
in VIII.1.4 that 'The unity of the Church universal is impaired but not destroyed by the denominational division of churches', on the basis that doctrinal differences need not and should not impede working together where denominations have a common interest in matters such as social justice. One does not need to agree on eschatology in order to oppose exploitation. Where the problem lies, or so it seems to me, is the statement in VIII.2.1 that each church 'should promote visible unity amongst the separated churches'. Mutual respect, certainly, but 'visible unity' looks to be an impossibility from a Quaker perspective: Friends would have to sign up to all sorts of doctrinal standards that they do not now hold - and probably never could.

\section{Church property}

Section IX, on church property, is as applicable to Friends as to any other denomination. Friends do not have any concept of 'sacred space' or 'consecrated ground' in the sense understood by, for example, the Roman Catholic or Anglican Church - but they do regard it as necessary to maintain buildings and burial grounds in good order.

\section{Church and state relations}

Historically, Friends have been opposed to the establishment of religion, possibly because the movement grew out of opposition to what its founders regarded as the formalism of the Church of England and possibly because early Quakers were imprisoned and tortured for their faith. ${ }^{36}$ They would hold to the view in X.1.1 that churches should 'cooperate with the State in matters of common concern, but each is independent in its own sphere' and there is no bar on Friends participating in party politics. Moreover, an important part of Quaker witness is to 'speak truth to power': 'We are trustees of a long tradition which has sought to bring our religious convictions into the world "and so excite our endeavours to mend it". 37

The models of church-state relations set out in X.1.3 appear to cover the position of religious communities in liberal democracies. 'The registration of a church in accordance with the provisions of any applicable State law' in X.1.3(4) cannot, however, be passed over without comment. It is not necessary in the UK for a religious group to register in order to function as a religious group; and registration of church buildings in England and Wales has two results: it is not possible to conduct a religious marriage ceremony except in a registered building ${ }^{38}$ and the fact of registration confers total exemption from

36 See, eg, the 'Testimony concerning Christopher Story (1648-1720)': 'He suffered imprisonment and spoiling of goods with much patience, which proved to be his lot pretty early, by wicked men who became informers, seeking his ruin, with many others; yet the Lord preserved him in faithfulness, and brought him clean through all these exercises' (QFP, 18.04). 
non-domestic rates. In some states parties to the ECHR, however, registration of religious groups can act as a serious brake on their activities and, in some jurisdictions, appears to have been put in place precisely to that end. In Slovakia, for example, the religious registration law that came into effect on 1 March 2017 requires that religious groups seeking legal recognition must provide, inter alia, evidence of having 50,000 adult members: an increase from the previous 20,000-member requirement that had been in place since 2007 . No religious community had been able to register since the earlier law was passed ${ }^{39}-$ and the compliance of such a threshold with Articles 9 and 11 ECHR must be regarded as highly questionable. ${ }^{40}$

In that connection, where X.2.1 declares that 'All humans, having been created in the image of God, share an equality of dignity and fundamental human rights', Friends would probably prefer, more simply, 'All humans share an equality of dignity and fundamental human rights'. It is, in any case, not beyond dispute that human rights have a religious foundation: Tom Bingham, for one, has argued cogently that they are a product of the Enlightenment. ${ }^{41}$ Equally, Friends, both corporately and individually, would strongly support the statements in X.2.2 and X.3 on human rights and social justice.

As to the relationship between Friends and public institutions, the statements in X.4 are again unexceptionable in terms of English and Scots law. Friends provide chaplaincy services in hospitals and prisons - though, unsurprisingly, given the terms of the Peace Testimony, ${ }^{42}$ there are no Quaker chaplains in the military. BYM does not, however, 'seek financial assistance from the State in the provision of spiritual care in public institutions', except in the very limited case of Quaker prison chaplains paid by the session. ${ }^{43}$

\section{CONCLUSION: THE VALUE OF THE STATEMENT}

As suggested above, given that the Quaker tradition is non-credal, British Friends are not, on the whole, very interested in doctrine; what concerns them is the outworking of their faith in everyday life. Moreover, they hold a wide range of beliefs: from those who maintain something resembling orthodox Trinitarian Christianity, albeit of a non-credal kind, through Unitarian/ Universalists and agnostics, to Friends who are avowedly non-theist.

38 The position is entirely different in Scotland and Northern Ireland.

39 L Ondrasek, 'Slovakia's new religious registration law is a step in the wrong direction', Providence: A Journal of Christianity a American Foreign Policy, 1 March 2017, available at $<$ https://providencemag. $\mathrm{com} / 2017 / 03 /$ slovakias-new-religious-registration-law-step-wrong-direction/ $>$, accessed 2 June 2018. Most recently on this point, see Bektashi Community and Others $v$ 'The former Yugoslav Republic of Macedonia' App nos 48044/10, 75722/12 and 25176/13 (ECtHR 12 April 2018).

41 T Bingham (Lord Bingham of Cornhill), 'Endowed by their creator?', (2005) 8 Ecc LJ 173-185.

42 QFP, 24.04.

43 See Miller v Secretary of State for Home Affairs [2004] UKEAT 00926/03/0405. 
The basic problem with the Statement is that it is - unsurprisingly grounded in an essentially Christocentric, Trinitarian theology and often proceeds from assumptions that a significant number of Friends would regard as adiaphora at best or, at worst, would reject completely. But that is not to suggest that the Statement is without value for Friends.

Given that Friends sit very lightly to doctrinal formulations, there is little reason why they should regard the doctrinal formularies of Trinitarian churches as an obstacle to working together on matters of common concern. Friends would no doubt support the exhortation of the World Conference on Faith and Order held in Edinburgh in 1937 'to practise such co-operation, to consider patiently occasions of disunion that they may be overcome [and] to be ready to learn from those who differ from them'. ${ }^{44}$ To that end, the Quaker Committee for Christian \& Interfaith Relations (QCCIR) has the task of keeping BYM informed about the various movements towards co-operation within the Christian church and opportunities for interfaith dialogue, and responds on BYM's behalf to other churches and faith communities. ${ }^{45}$ But it is not an easy task. Ben Pink Dandelion has noted that

there is a constant tension between maintaining belief in the integrity and worth of one's own identity while being open to learning from and about those of different persuasions. British Quakers are particularly cautious about those groups that claim to have found the 'final word', in contrast to the Quaker sense of the ever-onward journey of faith. In fact, it is sometimes easier for Quakers to engage with people of distinctly different faiths than with other Christians who maintain the same categories of belief but on different terms. ${ }^{46}$

To conclude: the counsel of Peter Meiderlin alias Rupertus Meldenius - 'In essentials, unity; in non-essentials, liberty; in all things, charity' - would probably sum up the attitude of most Friends to ecumenical discussion. ${ }^{47}$ The problem, however, is how to tease out the essentials.

For the current position, see QCCIR, A Spirit-led Church: a response from the Religious Society of Friends (Quakers) in Britain to World Council of Churches Faith and Order Paper No 214, The Church, towards a common vision, Geneva 2013 (London, 2016).

45 QFP, 9.13.

46 B Pink Dandelion, The Changing Face of Faith in Britain: how should Quakers respond? Part 3: charting Quaker ecumenical and interfaith involvement (London, n.d.), p 6, available at < https://quaker-prod.s3.euwest-1.amazonaws.com/store/do715f67729cf8b51188954fiob4957036d8de73ef38758a854egc18bfed >, accessed 7 June 2018.

47 'Si nos servaremus in necessariis unitatem, in non necessariis libertatem, in utrisque caritatem' (P Meiderlin, Paraenesis votiva per Pace Ecclesia ad Theologos Augustana Confessionis auctore Ruperto Meldenio Theologo (Rottenburg, 1626)). 